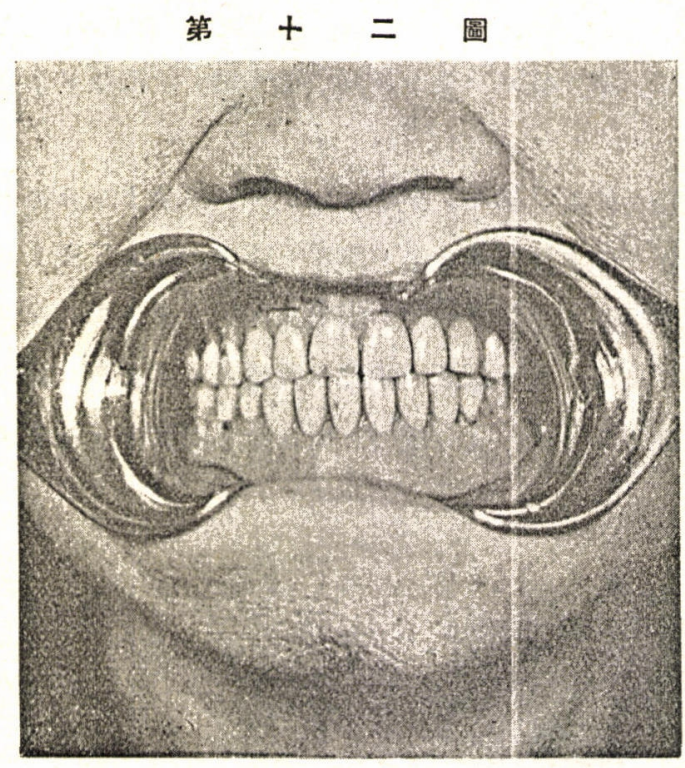

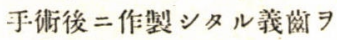
患萑二裝著セシメテ前方刍 リ見タル處ナリ

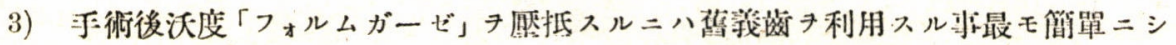
テ其ノ成績モ亦良好ナリ。

4) 創面ガ全ク治瘾スルニ至ル迄二ハ少クトモ6 週間ノ時日キ要ス, 從ツテ此ノ手 術ヨ受ケムトスルモノ八實際甚ダシキ困難ヨ感ズル者ニ非ザレバ, ヨク此ノ手術二媅 フル事ヨ得ザルベシ。少ホ此手石八大橋二郎君卜其二之レキ施シ，患者ノ後處置八全 部同氏ニ之レキ委任シタリ, 又莪苳ノ調製ハ小杉信三久君ノ手キ煩シタルモノナリ。

\title{
姡娠期二發生セシ巨大ナル齒躴腫ノー例二關スル臨牀的及組糡學的觀察
}

Klinische und histologische Beobachtungen ïber eine während der Schwangerschaft gewachser:en grossen Epulis.

Von Dr. K. Shibata und Dr. Y. Ohmagari(Aus der Klinik der Zahnärztlichen Hochschule zu Kyushu, Japan.)

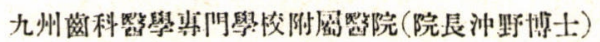

$$
\begin{aligned}
& \text { 新畑小一郎 } \\
& \text { 大曲站年 }
\end{aligned}
$$

Verfasser haben die Entstehung eines Falles von Epulis während der erstmaligen Schwangerschaftsdauer bei einer 23 jährigen Frau beobachtet. Der Patientin ist von einem Zahnarzt der $\overline{5}$ (distale Karies) behandelt und mit einer Goldkrone versehen worden. Kurz danach hat sie die Anschwellung 
am Gingivalrand zwischen $\sqrt{5}$ und $\sqrt{6}$ bemerkt. Hierauf hat die Patientin die Goldkrone entfernen und das gewachsene Gewebe mehrmals exzidiaren lassen. Aber doch ist die cingivaanschwellung an der gleichen Stelle immer wieder, und jedesmal grösser gewachsen. In jener Zeit hat sie die Symptome der Schwangerschaft bemerkt. Sie hat aus Furcht vor der chirurgischen Operation nicht gern die Epulis extirpieren lassen wallen. 6 Monate nach der Entbindung hat sie uns aufgesucht. Nach der klinischen und histologischen Untersuchung können wir Folgendes zusammenfassen: Die Ursache für die Entstehung dieser Epulis kann in den Reizzuständen des Periostes der Kiefer, durch die Abschleifung des Stumpfzahnes durch den Kronenring, und durch die viermalige unentschiedene Operation gesucht werden. Die Schwangerschaft könnte auch eine grosse Bedeutung für das Entstehen und das schnelle Wachstum dieses Fallen haben. Nach ca. 18 Monaten ist die Epulis zur Evergrösse mit Knochenresorption und Zahnlockerung in der Umgebung gewachsen. Die obere Hälfte derselben ist mit einer Pseudomembran bedeckt und sehr leicht blutend, während die untere mit Plattenepithel dicht bedeckt ist. Nach der Exstirpation mit Alveolarknochen und Extraktion der $\longdiv { 4 5 6 7 }$ ist dieser Fall ohne Rezidiv ausgeheilt. Histologisch zeigte eiese Epulis ein dem Hämangiom sehr ähnliches Bild.

\section{腥 害}

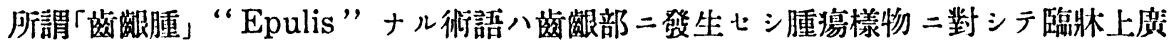
䉝二用ヒラレ或ル者八苜银二關連シタル大ナル顎骨腫瘍きモ含メ，又他ノ者ハ小ナル

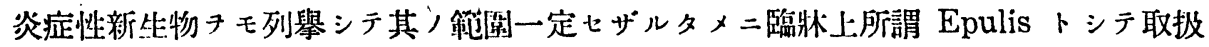
ハル、モそレキ組㵶學的二觀察スルトキハ學者間，見解二ッ二異ナリ，一ッハ具性ノ

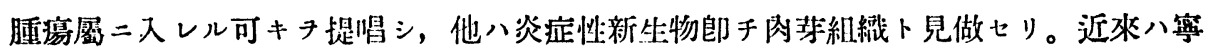
口後帒丹持スル者多ク Siegmund, Weber, Rywiund, Dawson, Struther, 正木等 アリ。

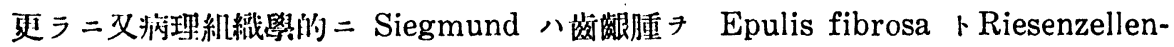
epulis トニ分類シ，後者八 Ostitis fibrosa カラ發生シ破肾或八㫮新生機軖ガ或ル

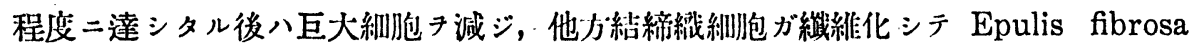

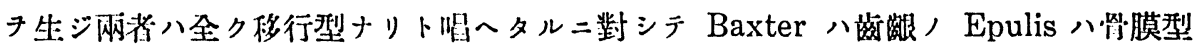

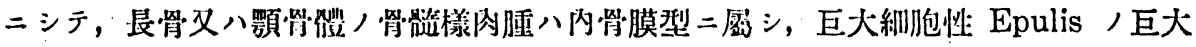




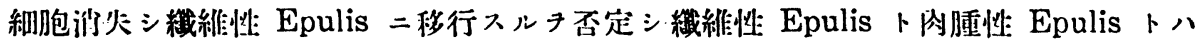
全ク異ナルモノトナセリ。

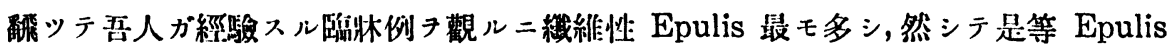

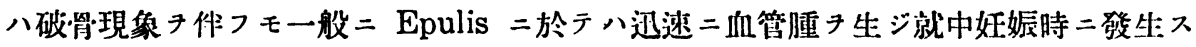
ル例ニテハ血管腫型最モ多ク頻發スト報告セラル。

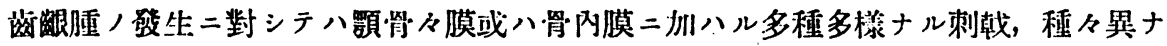

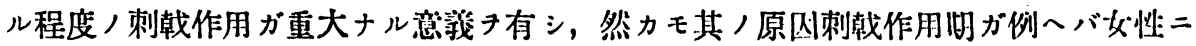

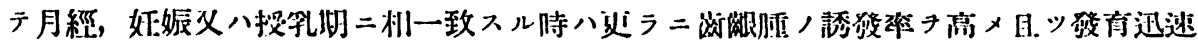

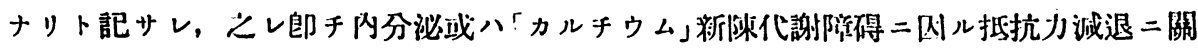
係スルナラント訟明七ラル。

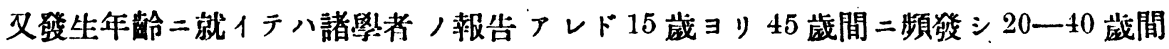
ノ青㰣年期二最モ多ク筑生スト記载ス, Gruner ノ統計二低レバ

\begin{tabular}{|c|c|c|}
\hline 1 藏 & 40 例 & $8.44 \%$ \\
\hline 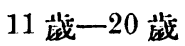 & 92 例 & $19.41 \%$ \\
\hline 21 蔵—30 歲 & 108 例 & 22.78 \\
\hline 31 藏-40 筬 & $11 \pm$ 例 & 24.0 \\
\hline 41 背— & 66 例 & 13.90 \\
\hline 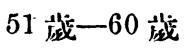 & 30 例 & 6.33 \\
\hline 60 歲以上: & 24 例 & 5.66 \\
\hline
\end{tabular}

キ示ス。

次二性別二就イテ諸學者ノ統計キ見レバ,

$\begin{array}{lcrrr}\text { Bloodgood 氏 } & \text { 男 } & 49 \text { 例 } & \text { 女 } & 118 \text { 例 } \\ \text { Bodcubach 氏 } & \text { 少 } & 2 \text { 例 } & \text { 女 } & 7 \text { 例 } \\ \text { Sarabie 氏 } & \text { 多 } & 5 \text { 例 } & \text { 女 } & 18 \text { 例 } \\ \text { Billroth 氏 } & - & \text { 女 } & 9 \text { 例 } \\ \text { Beckmann 氏 } & \text { 男 } 13 \text { 例 } & \text { 女 } & 29 \text { 例 } \\ \text { Richter 氏 } & \text { 男 } 11 \text { 例 } & \text { 女 } & 17 \text { 例 } \\ \text { Partsch 氏 } & \text { 男 } 23 \text { 侧 } & \text { 女 } & 92 \text { 侧 }\end{array}$

トアリ女子ハ男子ノ約 2 倍强頻攽スル事ガ背ゼラル。

\section{症 例}

患者 女性 23 荿(初妊娠 7 ケH)

饵往症 生來極メテ健康ニシテ特記スベキ报项ナシ。

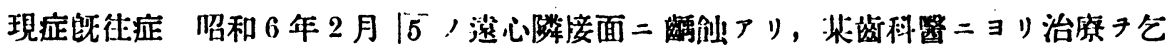




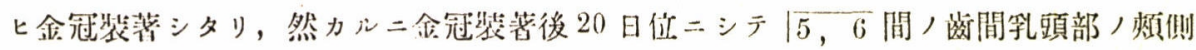

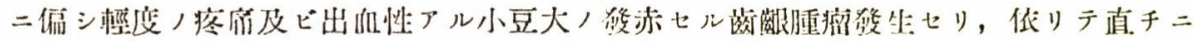

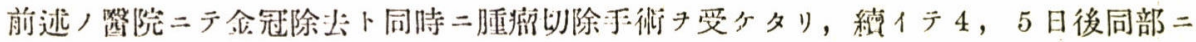

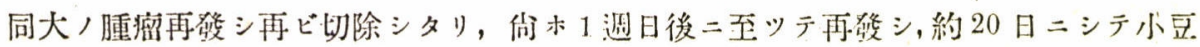

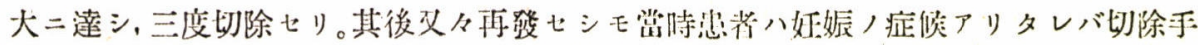

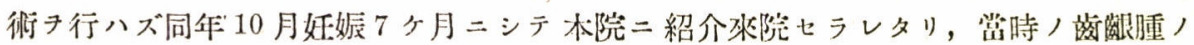

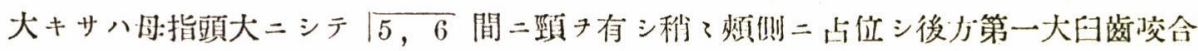

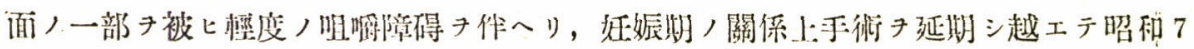
年 1 月昌兒子分娩シ同 6 月來院シ手術子乞へリ。

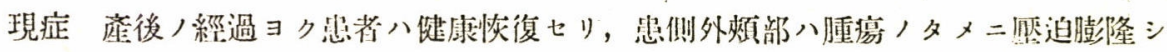

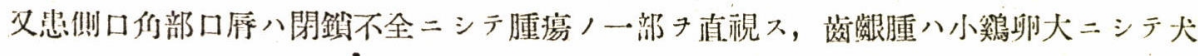

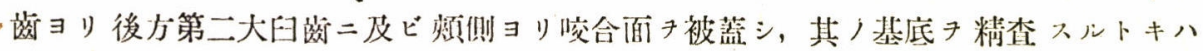

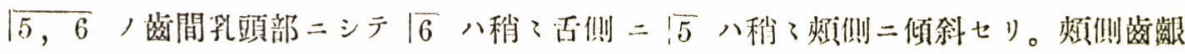

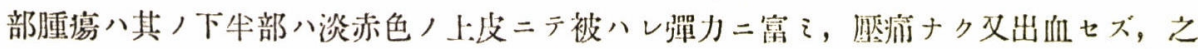

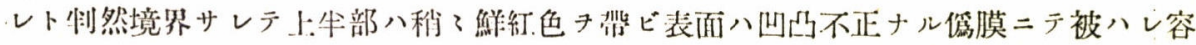

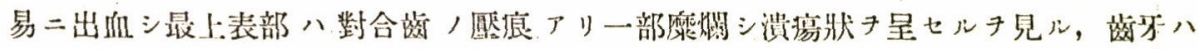

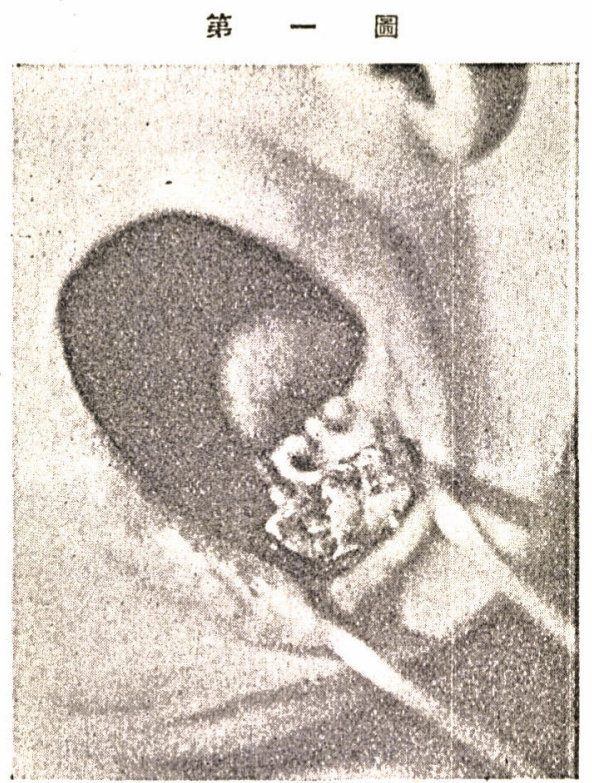

虫者初妊帮 23 歳 $\overline{4-7}$ 部二檠尘: セシ「エプーリフリヨ示ス

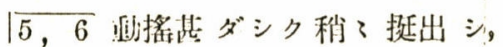
$\sqrt{4,7}$ モ織分弛緩シ虑レリ(第一, 第 二丈ビ第三圖參照)。

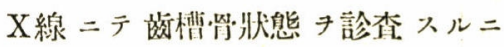
$\sqrt{5}$ 及ビ $\mid \overline{6}$ 八腫澺增生ノタメ明迫七

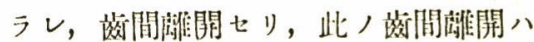
腫境弡生前ニハ全クナシト阔診二テ知 ル，父該部／落椯突起八水平的二吸收

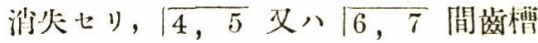
突起八著變ナシ (第四圖參照)。

處置手衐二先キダチ「トロンボー ゲン」10 c.c.尹內服七シメ，局所廊醉，

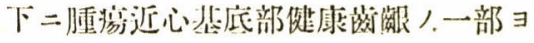

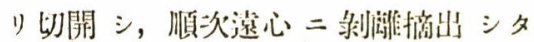

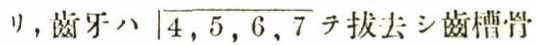




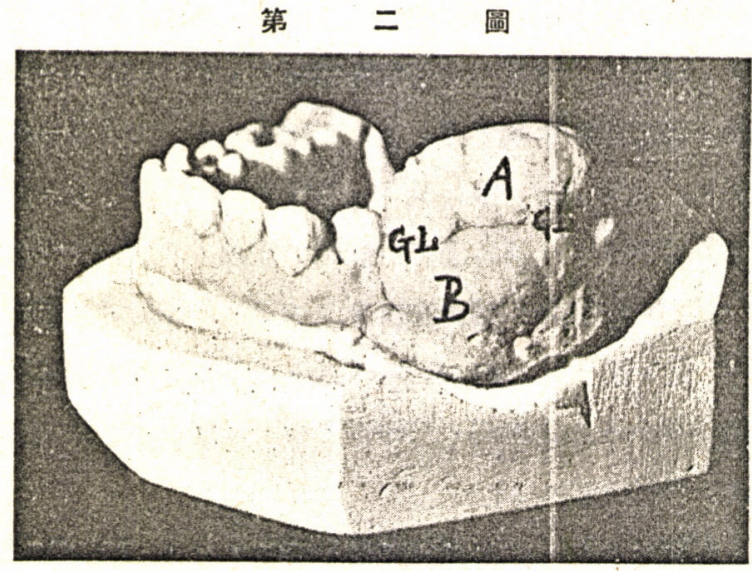

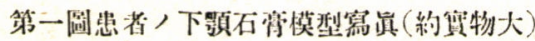

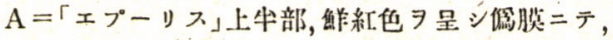
$\mathrm{B}=$ 下牛基底部八淡紅色上皮ニテ被ハレ, 境界線 GL 明㬗ナ゙リ

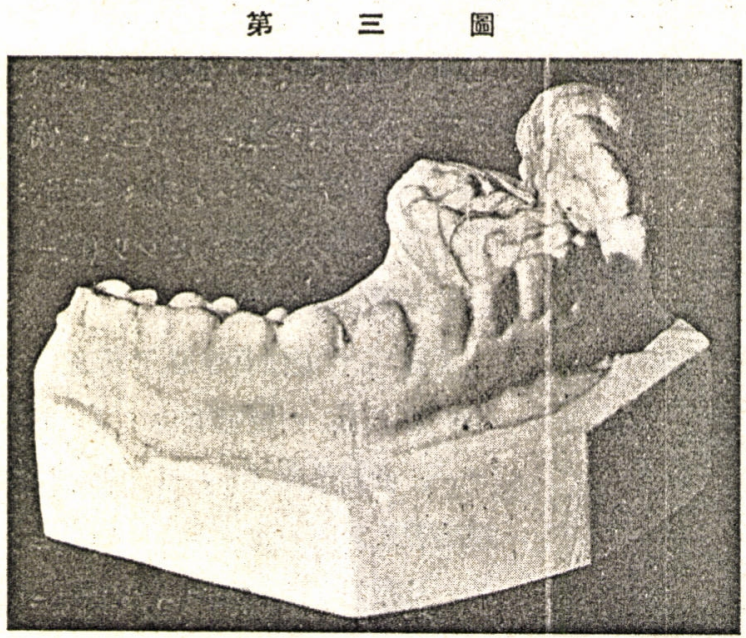

第二圖二同ジ，近心舌侧ヨリ觀タルヨ示ス
图切除光无分行へリ，手術 當初ヨり出血蘛ダシク, 殊二 $\overline{5,6}$ 間, 齒槽, 面ヨリハ激シキ㴮出血ア リタリ，手衍部八縫合シ テ手術キ終ル, 手術後疼 洴, 出血異二ナク經過極 メテ順調ニシテ 4 日後二

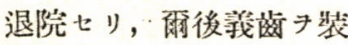
置シ 8 ケ月/ 今日腫㿑再 發ナシ。

摘出腫梡縕織及ビ齒牙 , 肉眼的所罗

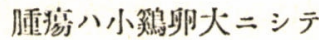
下牛部八淡赤色上皮縕䄉 二テ被ハレ滑澤ナル表面 チ旺シ，上牛部八鮮紅色 俗膜ニテ被ハレ表面容易 二破レ易シ，上下:牛部， 境界二八明暸ナル满狀 「クビレ」キ見ル（第二及 ビ第五圖參照)。

莮牙八形態, 大キサ, 發育二異常ナク第五圖二 示ス如ク $\sqrt{5}$, 遠心部,

$\sqrt{6}$, 近心部及ビ根分岐間二マデ增生肉莱樣組織, 附著七ルキ見ル, 又 $\mid \overline{4}$ 及ビ $\mid \overline{7}=$ 八斯カル狀態ナシ。

腫㾤組㵶, 顯溦鏡的所見

摘出セシ腫瘍組織キ先ヅ $10 \%$ 「フォルリン」液ニテ固定シタル後通法ニヨリ「チェ

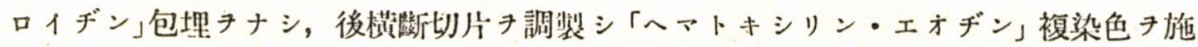
シえタ鏡見セリ。 


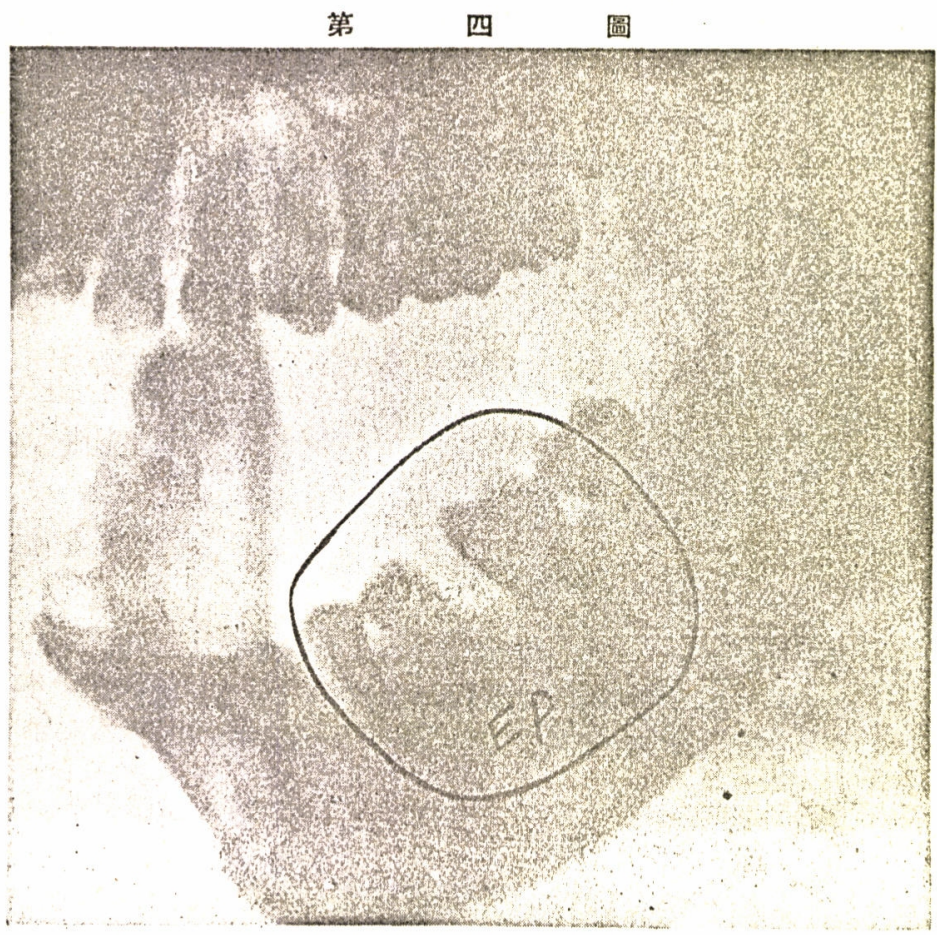

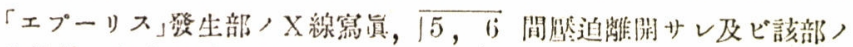

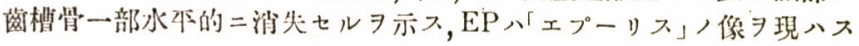

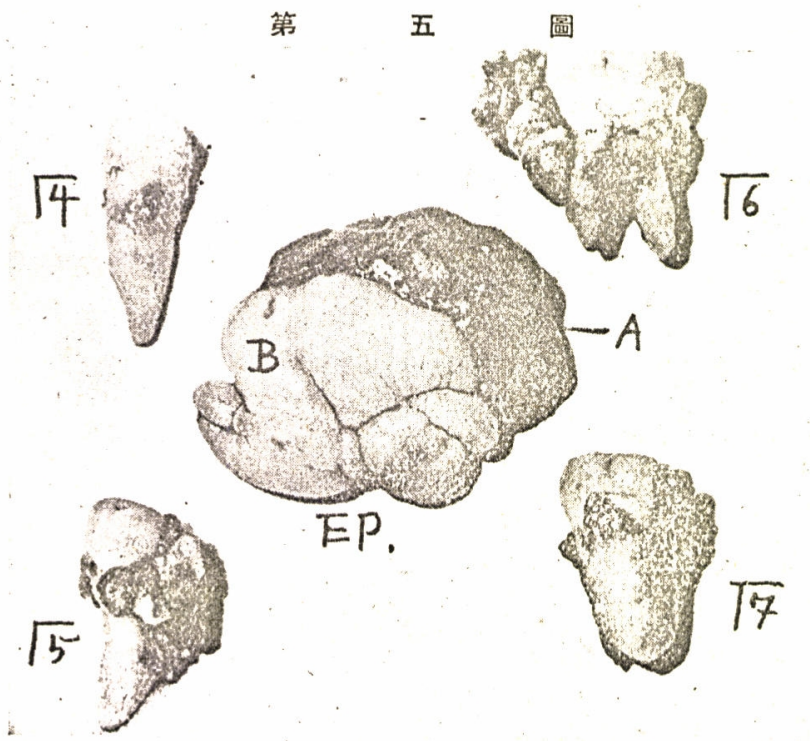

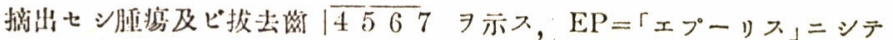

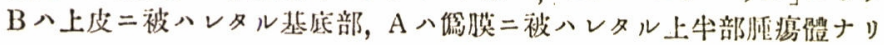




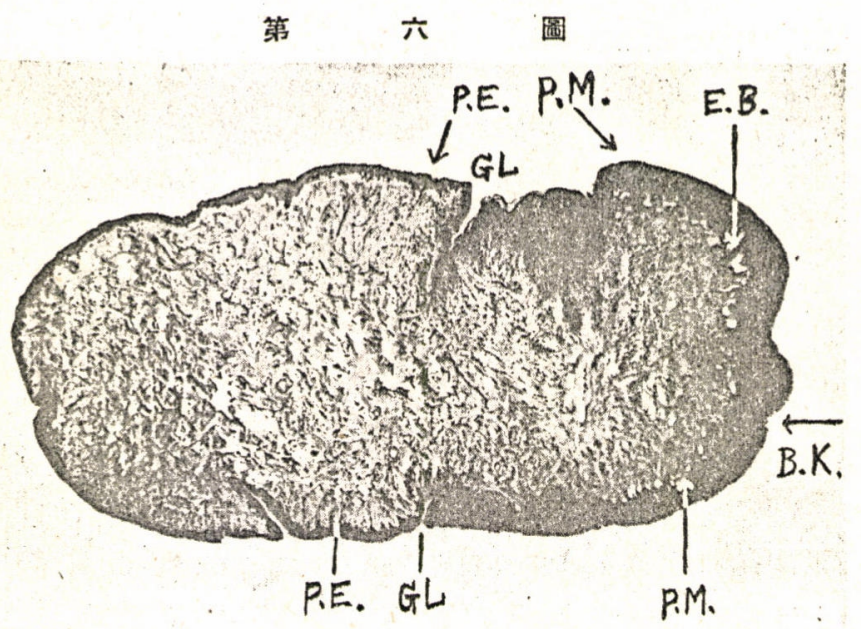

摘出セシ「ェプーリス」䊩面习示ス。 GL=右侧罢膜ニテ被 ハレタル上牛部膗瘍部卜左侧上皮二テ被ハレタル基底部卜，

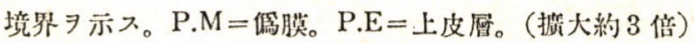

第七圖

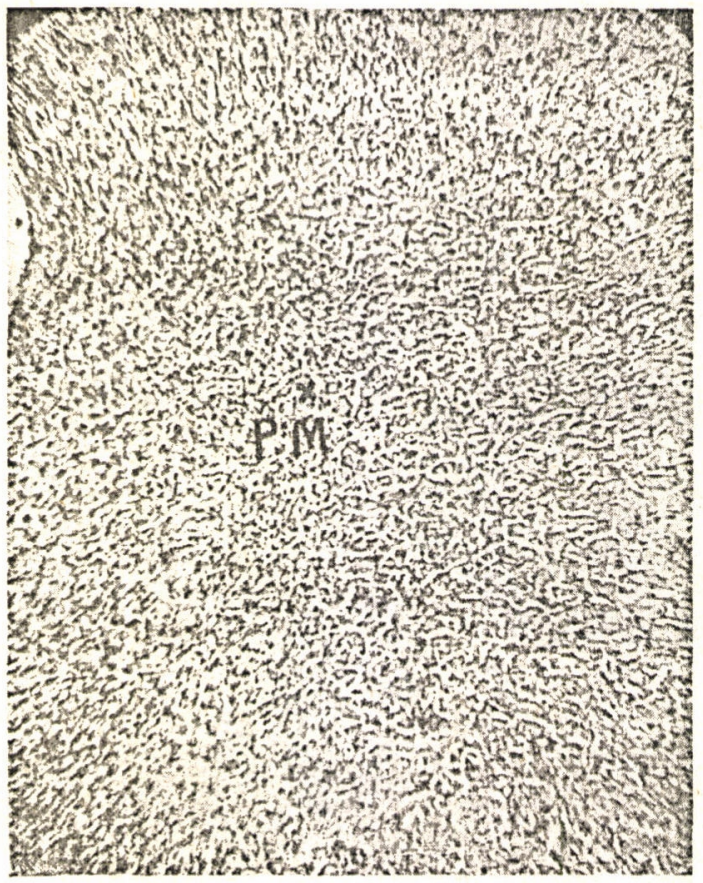

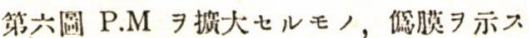

第六圖ハソノ 3 倍摭大顯微 鏡寫県圖ニシテ前記肉腿的所 見第二圖及ビ第五圖二示ス如 ク水阔二於テモ腄瑒ノ上下牛 部ノ境界チ㒫ル，腫疼基底部 約二分,一部 (第六圖左) 人外

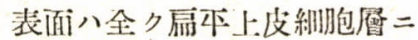
テ澥繞セラレ居ルチ胃ル。残

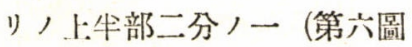
右），外表面八特ニ「エオヂ ン」ニテ澧染セラル,コノ部分 丹鏡兄振大久ル二纎維素/滲 出卜同時二滲出物及ビ壞死組 䄉 混和七儿膜樣物所謂祳膜 (Pseudomembran) チ生ジ, 光彩子放于，師于寞布垤里 (Diphterie) 状卜稱スべキ狀

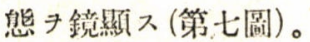




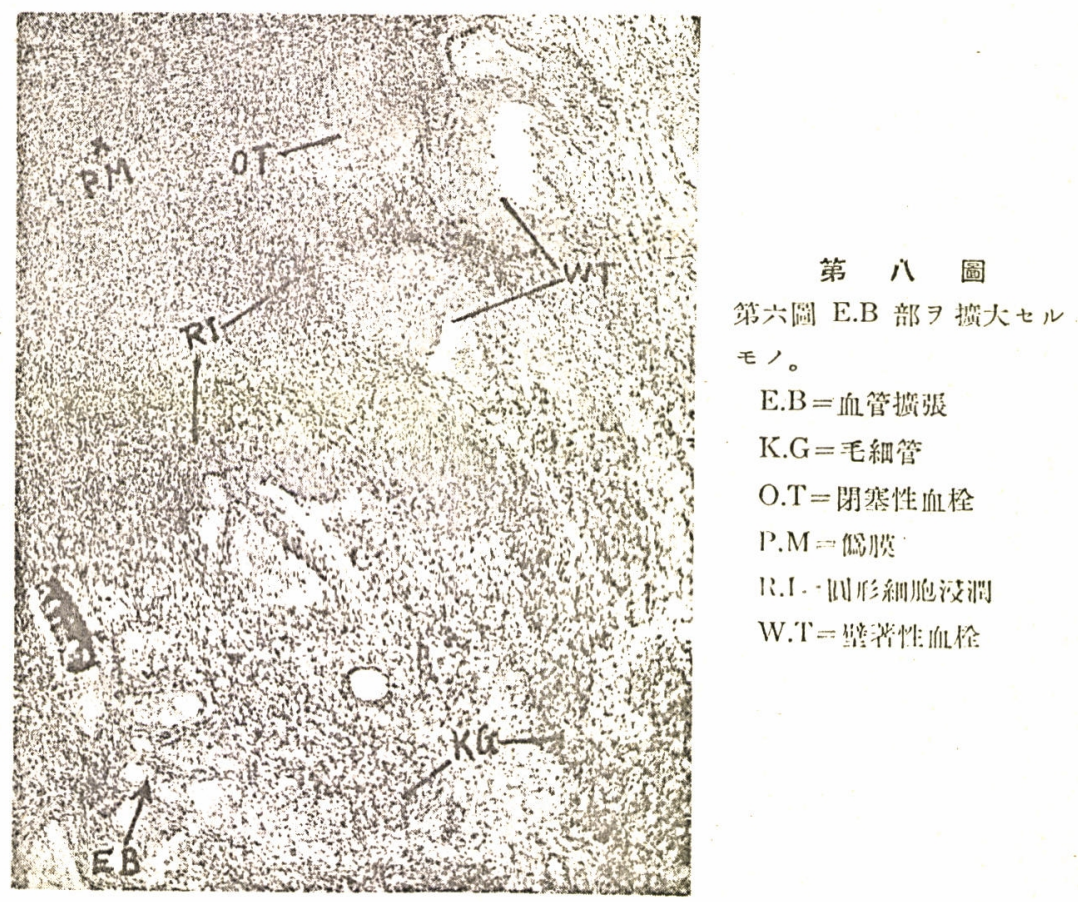

第九 圆

腫椱深層部, 內皮細胞二 雷 三, 毛細血管(K.G) 多 数 习有不。

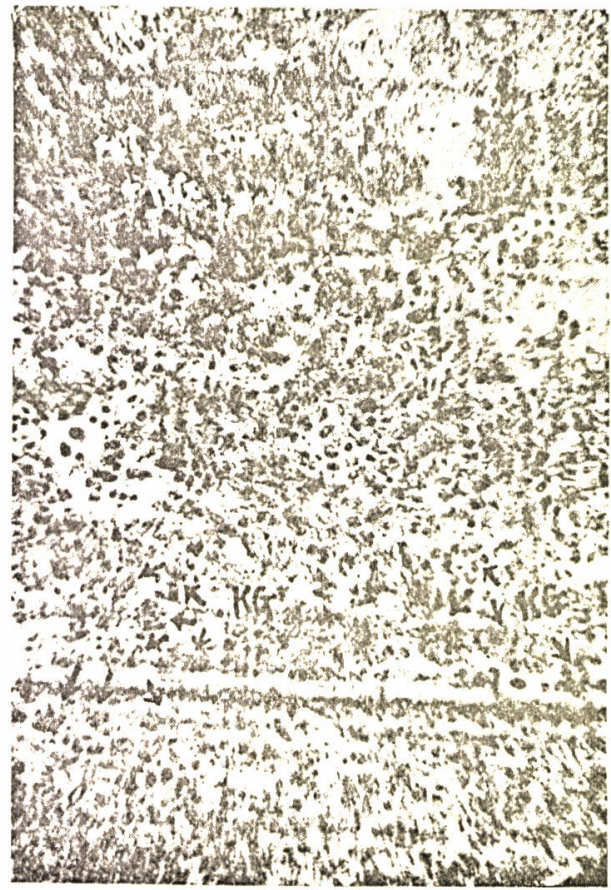




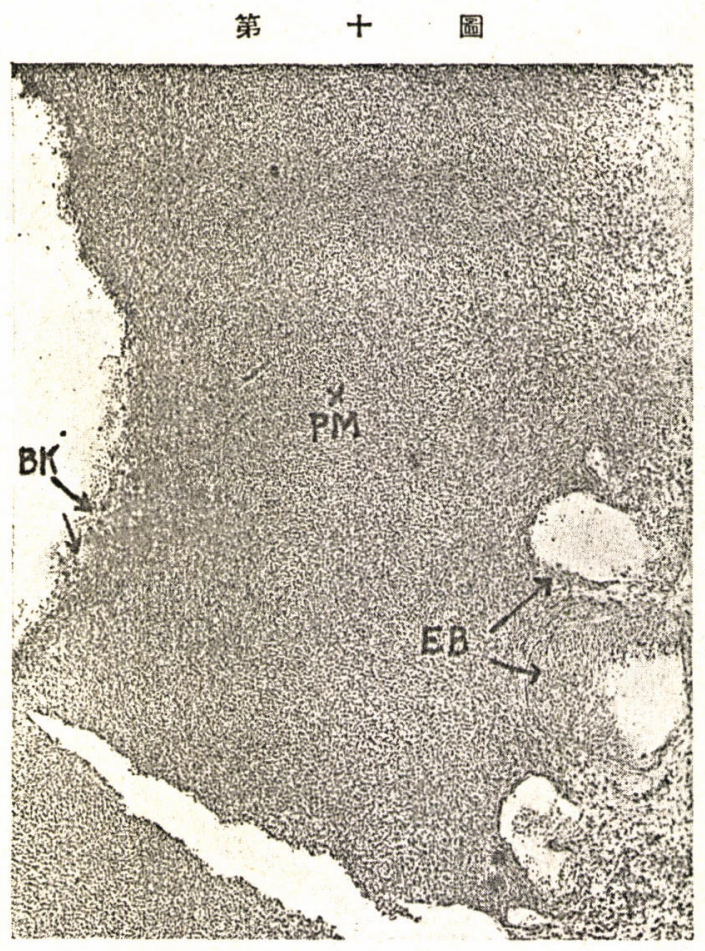

第六圖， B.K 部习㨿大七ルモ。

B.K=細菌塊 P.M =偦膜 E.B =搬張セル血管
是等笀膜下層ノ表面二近キ 血管ハ總テ摭张シ血行八停止: シ，處々二衈栓主トシテ硝子 樣血栓 (hyaliner Trombus) キ生ゼルキ認ム。是等八處二 ヨリテハ血管キ全ク无滿シ閉 塞性盂栓ヨ, 或ハ壁著性烅栓 チ形成セり(第八圖)。

是等ノ深層キ見ル二內波䊶 胞ニテ滿タサレタル部分ア リ, 此處八多數ノ小血管師于 毛絒恤管ニテ尤タサレ、コノ 部ノ內皮細包八著シク肥厚シ テ，所謂肥大性單純性助管腫 (Amgioma simplex hypertrophicum) トモ云ハル可キ 變化テトレリ(第孔圖)。

佮ホコ, 附近一帶二八中等

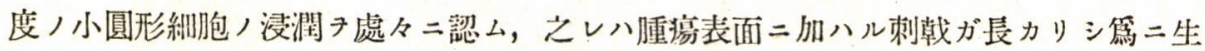

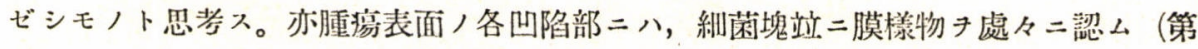
十圖)。

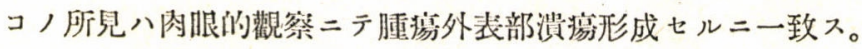

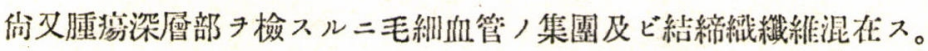

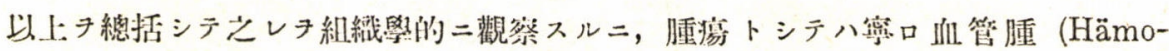
angioma) 二近キ造蓝チ岂ル。

總 括

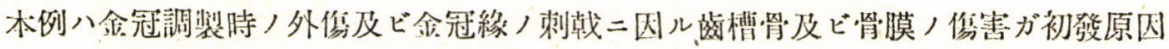

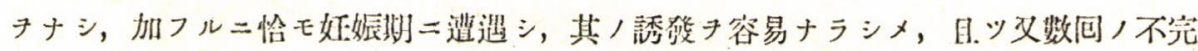

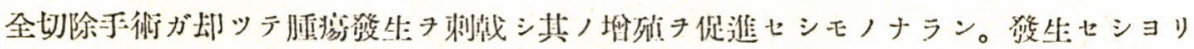
約 1 ケ年生ニシテ小鷤卵大二增大シ基底部八上皮二テ被ハレシモ上表面部ハ俘膜ニテ

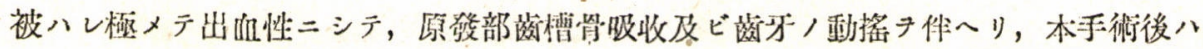


再浸七ズ。

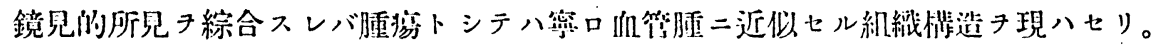

\section{文䃒}

1) Albertini, Gutartige Riesenzellengeschwülste. Ein vergleichend histologische Untersuchung. 1928. Leipzig. 2) Baxter, A Study of Myeloid Epulis and its Relationship to Myeoloid Sarcoma of the Long Bones. (British. Dental. Journal. No. 2. 1930) 3) Kantorowicz, Klinische Zahnheilkunde. 4) Siegmund u. Weber, Pathohistologie der Mundhöhle. 5) Port u. Euler, Lehrbuch der Zahnheilkunde. 6) Tholen and Frederick S. Balyeat, Epulis of the Jaws (Pacific Dental. Gazette. No. 4. 1930) 7) 正水正, 所詶「

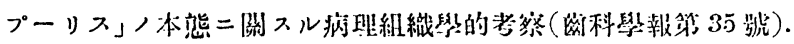

\section{烏㖨突起部二埋伏セル下顎智齔ノ稀有ナルー例}

Ein selten Fall von Latenzweisheitszahn in der Processus coronoideus-gegend.

Von Kunio Kusunoki.

(Aus der zahnärztlichen Klinick der Kaiserl. Universität zu Keijo, Korea, Japan. Vorstand Dr. N. Ikuta.)

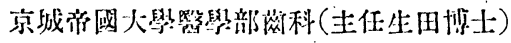

梢咸焳

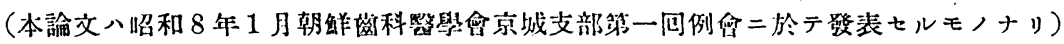

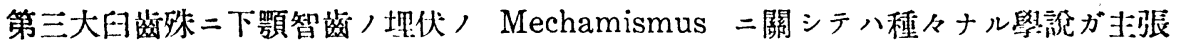

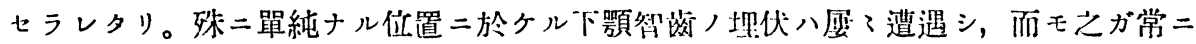

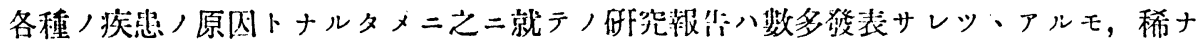

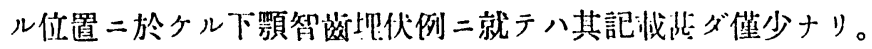

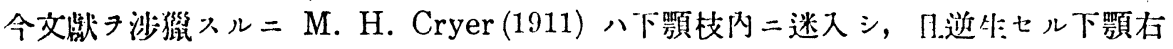

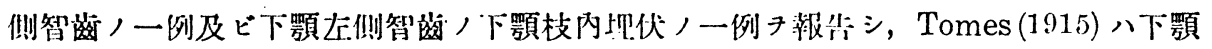

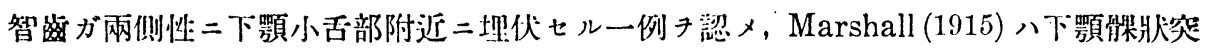

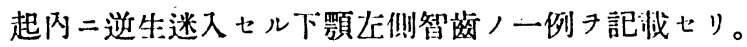

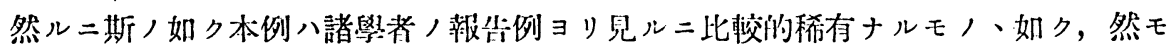

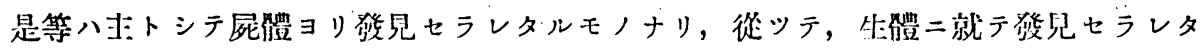
ル記械ハそ二比シテ一厲稀有ナルモノノ如シ。

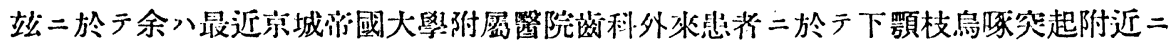

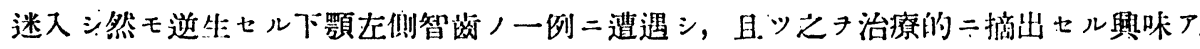

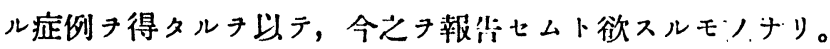

